\title{
Pengaruh aplikasi gel teh hijau (Camellia sinensis) terhadap kadar total antioxidant capacity (TAOC) sebagai perawatan tambahan dari skeling dan root planing pada pasien dengan periodontitis kronis
}

\author{
Nita Nurniza ${ }^{1 *}$, Ina Hendiani ${ }^{2}$, Ira Komara ${ }^{2}$ \\ ${ }^{1}$ Departemen Periodonti, Fakultas Kedokteran Gigi Universitas YARSI, Indonesia \\ ${ }^{2}$ Departemen Periodonsia, Fakultas Kedokteran Gigi Universitas Padjadjaran, Indonesia \\ *Korespondensi: doknita@gmail.com \\ Submisi: 9 Juni 2020; Penerimaan: 29 Agustus 2020; Publikasi online: 31 Agustus 2020 \\ DOI: $\underline{10.24198 / \mathrm{jkg} . \mathrm{v} 32 \mathrm{i} 2.27771}$
}

\begin{abstract}
ABSTRAK
Pendahuluan: Mekanisme peradangan periodontitis kronis menghasilkan reaksi oksidasi, diketahui melalui kadar total antioxidant capacity (TAOC) cairan sulkus gingiva. Teh hijau dapat menghambat bakteri patogen periodontal sehingga kerusakan jaringan periodontal tidak bertambah parah. Tujuan penelitian adalah menganalisis kadar TAOC sebelum dan sesudah skeling dan root planing disertai gel teh hijau sebagai antioksidan. Metode: Jenis penelitian eksperimen semu, rumus ukuran sampel untuk menguji perbedaan dua rata-rata data tidak berpasangan, setiap subyek memiliki poket $\geq 5 \mathrm{~mm}$, dikelompokkan sisi uji $(n=14)$ dan sisi kontrol $(n=14)$ (split mouth). Pengambilan cairan sulkus gingiva dilakukan pada hari ke-0, 15, dan 30, menggunakan metode absorbing paper strip dengan cara intracrevicular. Kedua sisi dilakukan skeling dan root planing, sisi uji diberikan gel. Hasil: Perbandingan kadar TAOC antara sisi kontrol dan sisi uji pada hari ke-0 $(p=0,986)$, hari ke-15 $(p=0,836)$, dan hari ke-30 $(p=0,371)$ menunjukkan tidak terdapat perbedaan bermakna $(p$-value $>0,05)$. Perbandingan rerata selisih kadar TAOC dalam kedua kelompok antara hari ke-0 dengan ke-15 ( $p=0,946)$, hari ke-0 dengan hari ke-30 $(p=0,504)$, serta hari ke-15 dengan hari ke-30 $(p=0,811)$ jugwa menunjukkan tidak terdapat perbedaan bermakna. Simpulan: Tidak terdapat pengaruh aplikasi gel teh hijau (Camellia sinensis) terhadap kadar total antioxidant capacity (TAOC) pada perawatan periodontitis kronis berupa skeling dan root planing.
\end{abstract}

Kata kunci: Gel teh hijau, periodontitis kronis, skeling dan root planing, total antioxidant capacity (TAOC).

\section{Effect of green tea (Camellia sinensis) gel application on the total antioxidant capacity (TAOC) levels as adjunct to scaling and root planing in patients with chronic periodontitis}

\section{ABSTRACT}

Introduction: The inflammatory mechanism of chronic periodontitis produces an oxidation reaction, measured through the level of total antioxidant capacity (TAOC) of the gingival crevicular fluid. Green tea can inhibit periodontal pathogenic bacteria so that periodontal tissue damage will not worsen. This study was aimed to analyse the levels of TAOC before and after scaling and root planing with green tea gel as an antioxidant. Methods: The research was quasi-experimental. The sample size formula was used to test the difference between two unpaired data means. Each subject has a pocket $\geq 5 \mathrm{~mm}$, grouped by the test side $(n=14)$ and the control side $(n=14)$ (split-mouth). The gingival crevicular fluid was collected on days 0,15 , and 30, using the intracrevicular method with absorbing paper strips. Both sides were treated with scaling and root planing, and the test side was administered with the green tea gel. Results: Comparison of TAOC levels between the control side and the test side on day $0(p=0.986)$, day $15(p=0.836)$, and day $30(p=$ $0.371)$ showed no significant difference ( $p$-value $>0.05)$. Comparison of the mean difference of the TAOC levels in two groups between day 0 with day 15 was $p=0.946$, day 0 with day 30 was $p=0.504$, and day 15 with day 30 was $p=0.811$; which also showed no significant difference. Conclusion: There is no effect of green tea gel (Camellia sinensis) application on the Total Antioxidant Capacity (TAOC) level in chronic periodontitis treatment in the form of scaling and root planing.

Keywords: Green tea gel, chronic periodontitis, scaling and root planing, total antioxidant capacity (TAOC). 


\section{PENDAHULUAN}

Periodontitis kronis merupakan salah satu penyakit yang terjadi dalam rongga mulut, penyakit ini diakibatkan oleh berbagai macam faktor salah satunya adalah bakteri pathogen periodontal yang terdapat dalam plak. Penyakit periodontitis kronis memiliki gambaran klinis meliputi pembentukan poket, resesi gingiva, attachment loss, kerusakan tulang alveolar, hingga dapat mengakibatkan kegoyangan gigi. ${ }^{1-3}$ Penyakit periodontitis kronis selain dapat didiagnosis melalui pemeriksaan klinis dapat juga melalui parameter cairan rongga mulut seperti saliva dan cairan sulkus gingiva untuk mengetahui tingkat keparahan. Cairan sulkus gingiva merupakan parameter yang paling banyak di teliti. ${ }^{4-6}$

Peradangan pada jaringan periodontal yang disebabkan oleh bakteri pathogen periodontal memicu terjadinya respon inflamasi dan ditandai dengan adanya aktifitas enzim proteolitik yang kemudian akan terbentuk radikal bebas.$^{7,8}$ Radikal bebas merupakan atom atau molekul yang memiliki satu atau lebih elektron yang tidak berpasangan dan memiliki sifat sangat reaktif. ${ }^{8,9}$ Reaksi yang terjadi antara radikal bebas dan jaringan akan terhenti apabila elektron tidak berpasangan pada rantai radikal bebas tersebut berikatan dengan antioksidan. Radikal bebas akan selalu terbentuk dalam tubuh ketika adanya pembakaran atau reaksi oksidasi dengan oksigen, proses tersebut akan dilanjutkan dengan detoksifikasi yang dilakukan oleh antioksidan. Mekanisme antioksidan terhadap adanya radikal bebas adalah dengan cara memberikan salah satu elektron bebas pada rantai antioksidan tanpa menyebabkan ketidakstabilan pada antioksidan itu sendiri kemudian mengubah molekul radikal bebas menjadi kurang reaktif, serta memfasilitasi perbaikan jaringan yang diakibatkan oleh radikal bebas. ${ }^{8-11}$

Antioksidan merupakan senyawa yang memiliki elektron bebas yang tidak berpasangan sehingga elektron tersebut dapat berikatan dengan radikal bebas sebagai salah satu sistem pertahanan tubuh agar terjadi keseimbangan antara oksidan dan antioksidan. Antioksidan berfungsi melindungi sel-sel dalam tubuh dari efek kerusakan yang ditimbulkan oleh radikal bebas, hal ini terjadi saat proses inflamasi sedang berlangsung. Salah satu indikator yang digunakan untuk mengukur adanya aktivitas antioksidan dalam tubuh adalah TAOC. TAOC menggambarkan aktivitas dari keseluruhan antioksidan terhadap adanya radikal bebas..$^{11,12}$ TAOC terdapat dalam cairan rongga mulut, selain pada saliva juga terdapat pada cairan sulkus gingiva. Penelitian mengenai kadar TAOC yang terdapat di jaringan periodontal sehat dan penderita periodontitis kronis telah diteliti sebelumnya. Kadar TAOC penyakit periodontitis kronis memiliki nilai yang lebih rendah dibandingkan dengan kondisi jaringan periodontal yang sehat. Perawatan inisial periodontal yaitu skeling dan root planing dapat meningkatkan kadar TAOC sehingga proses peradangan lebih lanjut dapat dihindari, serta proses penyembuhan berlangsung di jaringan periodontal. ${ }^{12,13}$

Sumber antioksidan terdiri dari antioksidan alami dan antioksidan sintetik. Antioksidan alami merupakan hasil ekstraksi dari bahan alami antara lain antioksidan lycopene dapat di ekstraksi dari tomat, kemudian catechin merupakan antioksidan yang berasal dari teh hijau, sedangkan antioksidan sintetik merupakan hasil dari adanya reaksi kimia. ${ }^{14-17}$ Antioksidan memiliki berbagai macam fungsi antara lain berfungsi sebagai preventive dan juga scavenger (chain breaking). Golongan polifenol merupakan salah satu antioksidan yang berfungsi sebagai scavenger (chain breaking), contohnya adalah catechin yang terkandung dalam teh hijau. ${ }^{18-20}$

Penelitian mengenai teh hijau menyebutkan bahwa teh hijau sebagai salah satu herbal tradisional dengan salah satu manfaatnya adalah sebagai antioksidan. Kandungan antioksidan dalam teh hijau yaitu cathecin memiliki kemampuan mengurangi kerusakan pada jaringan yang diakibatkan oleh radikal bebas serta dapat meningkatkan kesehatan gingiva. ${ }^{21-23}$ Catechin yang berperan sebagai scavenger radikal bebas yaitu dengan memberikan salah satu elektron bebas kepada radikal bebas sehingga aktivitas radikal bebas terhenti, tidak menyebabkan kerusakan pada jaringan periodontal lebih lanjut, serta memperbaiki jaringan. ${ }^{24,25}$

Perawatan skeling dan root planing bertujuan untuk menghilangkan salah satu etiologi penyakit periodontitis kronis yaitu plak bakteri. ${ }^{1-3}$ Perawatan tersebut termasuk ke dalam fase inisial periodontal untuk mencegah inflamasi lebih lanjut. Perawatan ini salah satunya dapat dilakukan dengan 
menggunakan ultrasonic scaler. ${ }^{4,5}$ Tindakan skeling dan root planing dapat dilakukan bersamaan dengan penambahan agen kemoterapeutik sebagai terapi tambahan dengan tujuan mengontrol flora bakteri, mengurangi peradangan, sebagai antioksidan sehingga mempercepat proses penyembuhan dan kondisi jaringan mengalami perbaikan. Salah satu agen kemoterapeutik yang dapat diaplikasikan dan memiliki kandungan antioksidan adalah catechin yang berasal dari teh hijau dapat membantu mengurangi peradangan serta mempercepat proses penyembuhan jaringan. ${ }^{25,26}$

Teh hijau memiliki berbagai macam manfaat dan dapat dikonsumsi setiap hari. Bentuk yang sering dijumpai adalah minuman, obat kumur, aplikasi obat secara lokal. Penelitian mengenai teh hijau menyebutkan bahwa teh hijau dapat menghambat bakteri patogen periodontal sehingga kerusakan jaringan periodontal tidak bertambah parah. Teh hijau yang di aplikasikan secara lokal seperti dalam bentuk chip, gel dapat dimasukan ke dalam sulkus gingiva, hal ini dapat juga membantu proses penyembuhan jaringan agar tidak mengalami kerusakan lebih lanjut. ${ }^{23,26}$ Proses peradangan yang terjadi pada penyakit periodontitis kronis menghasilkan radikal bebas akibat adanya reaksi oksidasi yang dapat menyebabkan kerusakan pada jaringan periodontal. Tingkat keparahan yang terjadi di jaringan periodontal dapat diketahui melalui seberapa besar TAOC yang terkandung dalam cairan sulkus gingiva, dalam hal ini apabila antioksidan yang ada mampu menetralisir radikal bebas, hal ini dapat membantu proses penyembuhan dan mengurangi kerusakan lebih lanjut. ${ }^{7-9,11-13}$

Tujuan penelitian adalah menganalisis pengaruh kadar TAOC pasca aplikasi gel teh hijau pada pasien periodontitis kronis sebelum dan sesudah dilakukan perawatan skeling dan root planing.

\section{METODE}

Jenis penelitian eksperimental semu dengan pengambilan sampel yaitu pasien yang datang ke Instalasi Periodonsia Rumah Sakit Gigi dan Mulut Universitas Padjadjaran (RSGM Unpad) sesuai dengan kriteria inklusi yaitu laki-laki dan perempuan berusia $30 \geq$ tahun, dengan hasil diagnosis periodontitis kronis, memiliki kedalaman poket $\geq 5 \mathrm{~mm}$ diukur dengan probe periodontal UNC 15 merk Osung, belum pernah menerima perawatan periodontal selama 6 bulan terakhir dari pemeriksaan ini, bersedia mengikuti penelitian dengan menandatangani informed consent. Empat belas subyek $(n=14)$ yang terpilih sesuai dengan rumus ukuran sampel untuk menguj perbedaan dua rata-rata data tidak berpasangan, plak supragingival dibersihkan dan gigi diisolasi menggunakan cotton roll agar tidak terkontaminasi oleh saliva, dilakukan pengambilan cairan sulkus gingiva menggunakan metode absorbing paper strip dengan cara intracrevicular yaitu paper strip dimasukkan kedalam sulkus gingiva sampai ke dasar sulkus dan didiamkan selama 30 detik. ${ }^{27}$

Penelitian ini menggunakan paper point no. $30^{27}$ dalam waktu 2-3 menit sehingga didapatkan 6-8 paper point dalam satu sisi poket, kemudian dimasukkan ke dalam tabung yang sudah diisi dengan phosphat buffer dengan perbandingan 1:1000 $\mathrm{ml}$ sebagai pelarut, selanjutnya dilakukan tindakan skeling dan root planing menggunakan ultrasonic scaler, setelah tindakan diberikan aplikasi gel teh hijau seperti pada gambar 1 sebagai terapi tambahan dengan cara dimasukan ke dalam sulkus gingiva sampai meluap kearah korona, dikategorikan kedalam kelompok uji dan dihitung sebagai hari ke-0. Gigi berseberangan yang memiliki kedalaman poket $\geq 5 \mathrm{~mm}$ dilakukan tindakan skeling dan root planing, namun tidak diaplikasikan gel teh hijau dan dikategorikan ke dalam sisi kontrol dan dihitung sebagai hari ke0 . Pasien diinstruksikan untuk tidak berkumur, meludah, dan makan selama 1 jam setelah aplikasi gel. Tabung yang sudah terisi paper point dibawa ke laboratorium untuk disimpan di lemari pendingin dengan suhu $-80^{\circ} \mathrm{C}$ dan akan dilakukan pemeriksaan secara bersamaan. Kriteria eksklusi yaitu mengkonsumsi antibiotik selama 6 bulan terakhir, wanita hamil atau menyusui, memilik riwayat penyakit sistemik (seperti diabetes mellitus, hipertensi, kelainan darah).

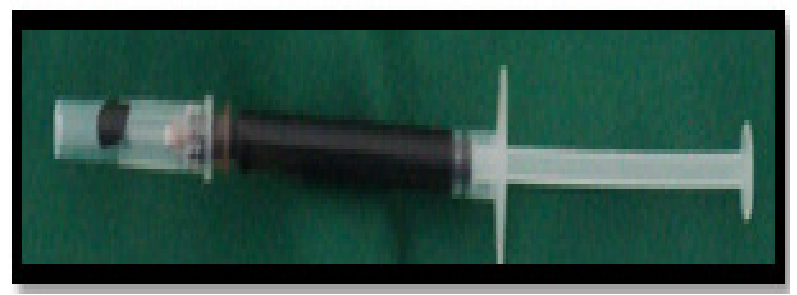

Gambar 1. Gel teh hijau yang sudah terdapat dalam syringe 
Kunjungan hari ke-15 dan hari ke-30 dilakukan pengambilan sampel cairan sulkus gingiva sesuai dengan prosedur yang dilakukan tanpa dilakukan pengukuran kedalaman poket, tidak dilakukan penambahan gel teh hijau dan tidak pula dilakukan perawatan skeling dan root planing. Hari ke-30 dilakukan tes ELISA untuk tes TAOC (Total Antioxidant Capacity) menggunakan My Biosource seperti pada gambar 2, gambar 3 dan gambar 4 .
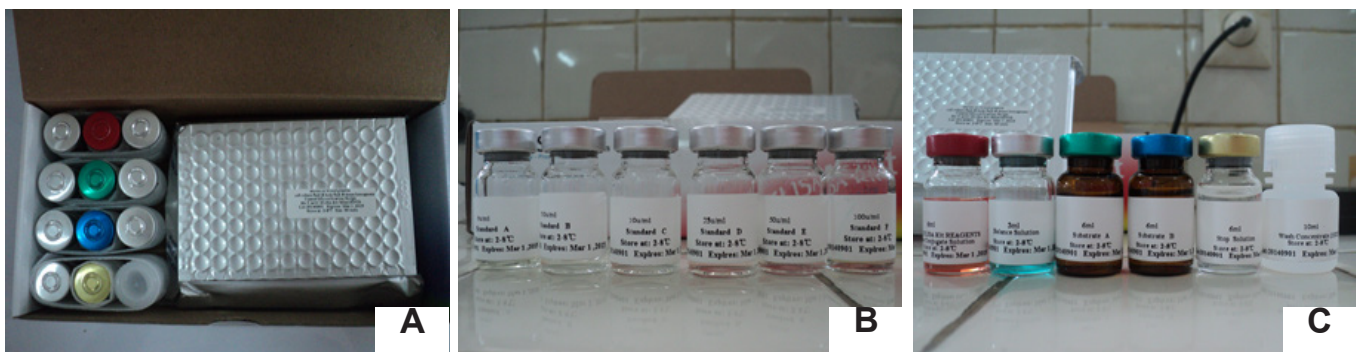

Gambar 2. A. Kit Elisa untuk tes T-AOC (Total Antioxidant Capacity) terdiri dari microtiter plate sebanyak 96 wells, enzyme conjugate 1 tube, larutan standard 6 tube, larutan substrate 2 tube, larutan stop solution 1 tube, larutan wash solution (100x) 1 tube, larutan balance solution 1 tube, dan 1 buku instruksi; B. Larutan standard terdiri dari standard A $0 \mu / m l$, standard B $5 \mu / \mathrm{ml}$, standard C $10 \mu / \mathrm{ml}$, standard D $25 \mu / \mathrm{ml}$, standard E $50 \mu / \mathrm{ml}$, standard F $100 \mu / \mathrm{ml}$; C. Larutan enzyme conjugate $6.0 \mathrm{ml}$, larutan balance solution $6 \mathrm{ml}$, larutan substrate A $6 \mathrm{ml}$, larutan substrate B ml, larutan stop solution $6 \mathrm{ml}$, larutan wash solution (100x) $10 \mathrm{ml}$
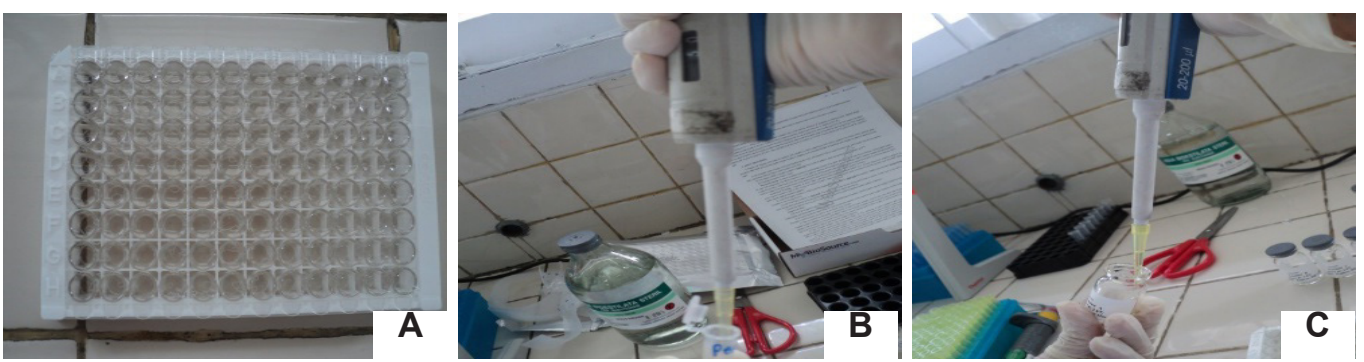

Gambar 3. A. Persiapan 96 wells, kemudian pada bagian pinggir wells diberi nomer agar memudahkan saat pembacaan di ELISA breader, pada well baris pertama khusus untuk larutan standar dari A - F; B. Setiap sampel diambil sebanyak $100 \mu \mathrm{L}$ menggunakan micropipet, kemudian diletakan dalam setiap wells; C. Larutan balance solution $10 \mu \mathrm{L}$, dan conjugate $50 \mu \mathrm{L}$ ditambahkan ke dalam seluruh sampel yang sudah ada dalam microtiter plate.
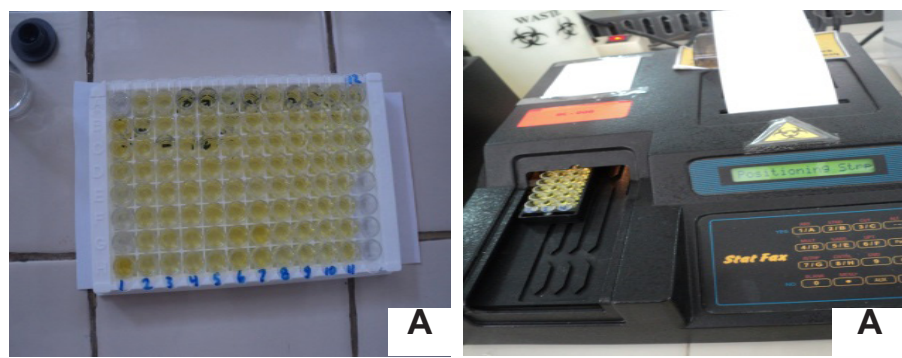

Gambar 4. A. Seluruh sampel telah dilarutkan dengan stop solution; B. Seluruh sampel dalam microtiter plate dilakukan pembacaan dengan ELISA reader pada gelombang $450 \mathrm{~nm}$

Penelitian sudah mendapat izin dari Komite Etik Penelitian Kesehatan dengan nomor 479/ UN6.C2.1.2/KEPK/PN/2014 dan izin penelitian di Rumah Sakit Gigi Dan Mulut (RSGM) Universitas Padjadjaran dan Laboratorium Patologi Klinik Rumah Sakit Hasan Sadikin. Analisis statistik pada penelitian ini menggunakan software SPSSPC versi 18, dengan uji unpaired t-test, uji Mann-
Whitney untuk menghitung nilai rata-rata kadar total antioxidant capacity (TAOC) antara kelompok uji dan kelompok kontrol, serta uji paired t-test dan uji Wilcoxon untuk menghitung nilai selisih ratarata kadar total antioxidant capacity (TAOC) antara kelompok uji dan kelompok kontrol, dan terlebih dahulu data diuji dengan uji normalitas Shapiro Wilk. 


\section{HASIL}

Hasil uji normalitas data (Tabel 1) menunjukkan data pada kelompok kontrol tidak berdistribusi normal di hari ke-15, sementara kelompok uji semua berdistribusi normal. Hasil uji beda di dalam kelompok kontrol dan kelompok uji juga menunjukkan bahwa data berdistribusi normal pada seluruh waktu uji. Hasil analisis statistik disajikan pada tabel-tabel berikut.

Tabel 2 di atas menunjukkan perbandingan kadar TAOC pada hari ke-0 antara kelompok kontrol dan kelompok uji berdasarkan uji independent $t$-test tidak terdapat perbedaan bermakna. Berdasarkan uji Mann-Whitney pada hari ke-15, kadar TAOC antara kelompok kontrol dan kelompok uji tidak memiliki perbedaan bermakna. Kadar TAOC pada hari ke-30 antara kelompok uji dan kelompok kontrol berdasarkan uji independent t-test dengan nilai $p$-value $>0,05$ menunjukkan tidak terdapat perbedaan bermakna.

Tabel 1. Hasil uji normalitas data kadar total antioxidant capacity (TAOC) kelompok kontrol dan kelompok uji menggunakan uji Shapiro-Wilk

\begin{tabular}{|c|c|c|c|}
\hline & \multicolumn{3}{|c|}{ Shapiro-Wilk } \\
\hline & Statistik & df & Nilai $p$ \\
\hline Usia responden & ,929 & 14 & ,299 \\
\hline $\begin{array}{l}\text { Kadar TAOC (kelompok kontrol) } \\
\text { di hari ke-0 }\end{array}$ & ,888 & 14 &, 075 \\
\hline $\begin{array}{l}\text { Kadar TAOC (kelompok kontrol) } \\
\text { di hari ke-15 }\end{array}$ & ,795 & 14 &, 004 \\
\hline $\begin{array}{l}\text { Kadar TAOC (kelompok kontrol) } \\
\text { di hari ke-30 }\end{array}$ & ,955 & 14 & ,643 \\
\hline $\begin{array}{l}\text { Kadar TAOC (kelompok uji) di } \\
\text { hari ke-0 }\end{array}$ & ,918 & 14 & ,205 \\
\hline $\begin{array}{l}\text { Kadar TAOC (kelompok uji) di } \\
\text { hari ke-15 }\end{array}$ & ,946 & 14 & ,496 \\
\hline $\begin{array}{l}\text { Kadar TAOC (kelompok uji) di } \\
\text { hari ke-30 }\end{array}$ & ,943 & 14 & ,455 \\
\hline $\begin{array}{l}\text { Selisih kadar TAOC (kelompok } \\
\text { kontrol) di hari ke-0 dan ke-15 }\end{array}$ & ,861 & 14 &, 032 \\
\hline $\begin{array}{l}\text { Selisih kadar TAOC (kelompok } \\
\text { kontrol) di hari ke-0 dan ke-30 }\end{array}$ & ,949 & 14 &, 545 \\
\hline $\begin{array}{l}\text { Selisih kadar TAOC (kelompok } \\
\text { kontrol) di hari ke-15 dan ke-30 }\end{array}$ & ,912 & 14 & , 170 \\
\hline $\begin{array}{l}\text { Selisih kadar TAOC (kelompok } \\
\text { uji) di hari ke-0 dan ke- } 15\end{array}$ & ,898 & 14 & ,106 \\
\hline $\begin{array}{l}\text { Selisih kadar TAOC (kelompok } \\
\text { uji) di hari ke-0 dan ke- } 30\end{array}$ & ,965 & 14 & ,802 \\
\hline $\begin{array}{l}\text { Selisih kadar TAOC (kelompok } \\
\text { uji) di hari ke-15 dan ke-30 }\end{array}$ & ,980 & 14 & ,972 \\
\hline
\end{tabular}

Tabel 2. Hasil uji perbandingan rata-rata kadar total antioxidant capacity (TAOC) antara kelompok uji dan kelompok kontrol

\begin{tabular}{|c|c|c|c|}
\hline \multirow[t]{2}{*}{ Pengamatan } & \multicolumn{2}{|c|}{$\begin{array}{c}\text { Nilai rata-rata kadar total } \\
\text { antioxidant capacity (TAOC) } \\
(\mathrm{N}=14)\end{array}$} & \multirow[t]{2}{*}{ Nilai $p$} \\
\hline & $\begin{array}{c}\text { Kelompok } \\
\text { uji }\end{array}$ & $\begin{array}{c}\text { Kelompok } \\
\text { kontrol }\end{array}$ & \\
\hline Hari ke-0 & 18,1 & 18,0 & $0,986^{a}$ (NS) \\
\hline Hari ke-15 & 19,4 & 20,8 & $0,836^{\mathrm{b}}(\mathrm{NS})$ \\
\hline Hari ke-30 & 17,5 & 21,1 & $0,371^{\mathrm{a}}(\mathrm{NS})$ \\
\hline
\end{tabular}

Keterangan: Nilai $p>0,05$, berdasarkan uji unpaired t-test (a), uji Mann-Whitney (b); NS = Tidak berbeda bermakna; Nilai Rata-rata (SD) kelompok uji $=18,1(7,3)$

Tabel 3. Hasil uji perbandingan selisih rata-rata kadar total antioxidant capacity (TAOC) antara kelompok uji dan kelompok kontrol

Nilai selisih rata-rata kadar total antioxidant capacity

\begin{tabular}{lccc} 
Pengamatan & \multicolumn{2}{c}{$\begin{array}{c}\text { (TAOC) } \\
\text { (N=14) }\end{array}$} & Nilai p \\
\cline { 2 - 3 } & $\begin{array}{c}\text { Kelompok } \\
\text { uji }\end{array}$ & $\begin{array}{c}\text { Kelompok } \\
\text { kontrol }\end{array}$ & \\
\hline Hari ke 0 - 30 & $-0,58$ & $-3,09$ & $0,504^{\mathrm{c}}(\mathrm{NS})$ \\
Hari ke $15-30$ & $-1,89$ & $-0,27$ & $0,811^{\mathrm{d}}(\mathrm{NS})$ \\
Hari ke 0 -15 & 1,31 & 2,82 & $0,946^{\mathrm{d}}(\mathrm{NS})$ \\
\hline
\end{tabular}

Keterangan: Nilai $\mathrm{p}>\mathbf{0 , 0 5}$, berdasarkan uji paired $t$-test (c), dan uji Wilcoxon (d); NS = Tidak berbeda bermakna; Nilai rata-rata (SD) HO - H30 kelompok uji = -0,58 $(13,31)$; kelompok kontrol $=3,15(15,71)$; Nilai rata-rata (SD) H15 $\mathrm{H} 30$ kelompok uji $=-1,89(16,67)$; kelompok kontrol $=-\mathbf{0 , 5 2}$ $(14,72)$; Nilai rata-rata (SD) HO $-\mathrm{H} 15$ kelompok uji $=1,31$ $(10,05)$; kelompok kontrol $=2,82(14,55)$

Hasil uji paired t-test tidak menunjukkan perbedaan yang bermakna dari kadar TAOC (tabel 3), yaitu perbandingan selisih rata-rata pada hari ke-30 dan hari ke-0 pada kelompok kontrol dan kelompok uji $(p$-value $=0,504)$ Hasil uji Wilcoxon juga tidak menunjukkan perbedaan yang bermakna dari kadar TAOC pada kelompok kontrol dan kelompok uji di hari ke-30 dan hari ke-15 berdasarkan ( $p$-value $=0,811)$. Begitu juga dengan kadar TAOC di hari ke-15 dan hari ke-0 pada kelompok kontrol dan kelompok uji menghasilkan $p$-value $=0,946$, sehingga tidak menunjukkan perbedaan yang bermakna.

\section{PEMBAHASAN}

Hasil analisis di tabel 2 dan 3 menunjukkan bahwa pada kelompok uji terdapat peningkatan kadar TAOC pada hari ke-0 dibandingkan hari ke- 
15 dan dibandingkan hari ke-30. Kelompok kontrol mengalami peningkatan kadar TAOC pada hari ke-0 dibandingkan hari ke-15 dan dibandingkan hari ke-30. Menurut Gupta ${ }^{28}$, kondisi jaringan periodontal dapat dilihat melalui cairan sulkus gingiva, saliva, serum darah, dari ketiga jenis ini cairan tubuh tersebut yang paling banyak diteliti dalam rongga mulut adalah cairan sulkus gingiva dan saliva, hal ini karena dapat mengetahui kondisi jaringan periodontal dan hasil perawatan yang telah dilakukan. Penelitian yang dilakukan oleh Hrishi et al. ${ }^{18}$, menyebutkan penggunaan pasta gigi dengan kandungan teh hijau selama 4 minggu dapat meningkatkan kadar TAOC dalam cairan sulkus gingiva. Teh hijau yang dapat digunakan dalam rongga mulut bisa dalam bentuk obat kumur, gel, dan chip. Penelitian Rattanasuwan et al. dan Chava et al.15,22, gel teh hijau dapat menurunkan kedalaman poket, gingival indeks dan bleeding on probing pada periodontitis kronis. Teh hijau digunakan sebagai terapi tambahan yang mengandung antioksidan catechin membantu meningkatkan penyembuhan dalam perawatan periodontitis kronis. Catechin mampu menetralisir radikal bebas yang terjadi pada proses inflamasi di jaringan periodontal. ${ }^{23,26}$ Kandungan antioksidan dalam gel teh hijau dapat membantu mengurangi proses inflamasi ${ }^{23-25}$, hal ini dibuktikan dengan hasil analisis pada penelitian ini yaitu peningkatan kadar TAOC pada kelompok uji. Kadar TAOC dalam cairan sulkus gingiva setelah dilakukan perawatan skeling dan root planing pada penderita periodontitis kronis mengalami peningkatan yang lebih tinggi dibandingkan pada jaringan periodontal sehat akibat danya proses penyembuhan jaringan. 4,5,12,29

Gel teh hijau dalam penelitian ini merupakan hasil ekstraksi daun teh hijau dan bukan hasil purifikasi zat aktif antioksidan yaitu catechin, sehingga memungkinkan kadar antioksidan yang terkandung menjadi lebih sedikit akibat tahapan proses pembuatan dari daun teh hijau menjadi gel. Faktor lain yang dapat mempengaruhi kandungan catechin yaitu jenis proses sebelum pengeringan, jenis teh hijau, persiapan infusi, kondisi pertumbuhan (misalnya tanah, iklim, pertanian, fertilisasi), kondisi geografik. Kandungan antioksidan catechin dalam teh hijau dapat mengurangi kerusakan yang diakibatkan oleh radikal bebas dan meningkatkan kesehatan gingiva. ${ }^{16,17}$ Teh hijau memiliki manfaat sebagai antibakteri, antioksidan, dan antikaries. ${ }^{22}$ Penelitian yang dilakukan oleh Kudva et al. ${ }^{25}$, menyebutkan bahwa teh hijau dalam bentuk strip memilik hasil yang baik setelah skeling dan root planing sebagai antimikroba. Menurut Venkateswara et al. ${ }^{23}$, dalam $100 \mathrm{ml}$ teh hijau rata-rata mengandung 5-100 $\mu \mathrm{gr}$ catechin dan memiliki manfaat sebagai antioksidan, antibakteri, antikaries. Penelitian lain menyebutkan bahwa dalam secangkir gelas teh hijau (2,5 gr daun the/ $200 \mathrm{ml}$ air) mengandung $90 \mathrm{mg}$ Epigallocatechin (EGCG) yang memilikii sifat antioksidan, antikarsinogenik, antiinflamasi, antimikroba. $^{23}$

Jumlah sampel dalam penelitian ini dikumpulkan mulai bulan September-Desember 2014. Penelitian ini memungkinkan terjadi kesalahan dalam pengambilan sampel yang bisa terjadi antara lain adanya kontaminasi cairan sulkus gingiva oleh darah, saliva atau dental plak, lamanya waktu pengambilan sampel. Gel teh hijau yang dimasukkan ke dalam sulkus diberikan satu kali pada saat hari ke-0 setelah skeling dan root planing, hal ini memungkinkan gel tersebut tidak lama berada dalam poket, misalnya pasien sering meludah atau berkumur.

Metode pemeriksaan cairan sulkus gingiva bermacam-macam, dalam penelitian ini dilakukan dengan tes ELISA dengan cara pengambilan sampel menggunakan paper point, metode ini yang paling banyak dilakukan. Kesalahan yang dapat terjadi pada hasil tes ELISA antara lain jumlah sampel yang tidak cukup sehingga tidak terbaca oleh breader, suhu ruangan yang tidak sesuai saat tes dilakukan. Kedua kelompok yaitu sisi uji dan sisi kontrol tidak mengalami perubahan yang signifikan, hal ini bisa terjadi karena jumlah sampel yang minim sehingga belum dapat meningkatkan signifikansi. Kandungan antioksidan gel teh hijau dalam penelitian ini tidak berpengaruh terhadap peningkatan kadar TAOC dalam cairan sulkus gingiva, hal ini memungkinkan bahwa penyakit periodontitis kronis belum sembuh dan kedalaman poket masih dalam sehingga dengan perawatan skeling dan root planing saja tidak cukup dan dibutuhkan perawatan lanjutan sesuai dengan rencana tahapan perawatan penyakit periodontal.

Peningkatan kadar TAOC dapat disebabkan karena adanya antioksidan dalam jaringan yang membantu dalam menetralisir radikal bebas. Penurunan kadar TAOC sebagai akibat dari 
kekurangan antioksidan dalam tubuh dan tidak ada tambahan dari luar misalnya terapi tambahan dalam bentuk suplementasi antioksidan dan aplikasi topikal yang mengandung antioksidan. ${ }^{9-12,23-26,30}$

\section{SIMPULAN}

Tidak terdapat pengaruh aplikasi gel teh hijau (Camellia sinensis) terhadap kadar total antioxidant capacity (TAOC) pada perawatan periodontitis kronis berupa skeling dan root planing.

\section{DAFTAR PUSTAKA}

1. Mathur A, Mathur L, Manohar B, Mathur $H$, Shankarapillai R, Shetty $\mathrm{N}$, et al. Antioxidant therapy as monotherapy or as an adjunct to treatment of periodontal diseases. J Indian Soc Periodontol 2013;17(1):21-4. DOI: 10.4103/0972-124X.107469

2. Armitage GC, Cullinan MP. Comparison of the clinical features of chronic and aggressive periodontitis. Periodontol 2000. 2010;53:1227. DOI: 10.1111/j.1600-0757.2010.00353.x

3. Nath SG, Raveendran R. "What is there in a name?": A literature review on chronic and aggressive periodontitis. $\mathrm{J}$ Indian Soc Periodontol 2011;15(4):318-22. DOI: 10.4103/0972-124X.92561

4. Vincent RR, Appukuttan D, Balasundaram A, Naik VK, Victor DJ. Total antioxidant/oxidant status in chronic periodontitis patients with type Il diabetes following nonsurgical periodontal therapy. Arch Med Health Sci 2020;8(1):41-6. DOI: 10.4103/amhs.amhs_12_20

5. Toczewska J, Maciejczyk M, Konopka T, Zalewska A. Total oxidant and antioxidant capacity of gingival crevicular fluid and saliva in patients with periodontitis: Review and clinical study. Antioxidants (Basel) 2020;9(5):450. DOI: 10.3390/antiox9050450

6. Newman MG, Takei HH, Carranza FA. Carranza's Clinical Periodontology. $11^{\text {th }}$ ed. Philadelphia: Saunders-Elsevier; 2012. h. 66$8,127,128,133,134,160-4,194-5,199-201,206$ 10,215.

7. Dahiya P, Kamal R, Gupta R, Puri A. Oxidative stress in chronic periodontitis. Chron Young Sci 2011;2(4):178-81. DOI: 10.4103/2229$\underline{5186.93019}$
8. Sebastian R, Shivarajashankara YM, Shantaram M, Ramachandrayya SA, Dayakar MM, Joshua A. Blood and salivary oxidantantioxidant status in chronic periodontitis: $A$ correlative study. Int J of Biochem 2013;2013: 273-80.

9. Sree SL, R Mythili. Antioxidants in periodontal diseases: A review. Ind J Multidiciplin Dent 2011;1(3):140-6.

10. Bakhtiari S, Taheri JB, Bakhshi M, Mortazavi $H$, Hoseini A S, Dastjerdi E V, et al. Effect of vitamin $C$ on salivary total antioxidant capacity in smokers. Iran J Pharm Res 2012; 11 (4): 1045-9.

11. Novakovic N, Cakic S, Todorovic T, Raicevic BA, Dozic I, Petrovic V, et al. Antioxidative status of saliva before and after non-surgical periodontal treatment. Srp Arh Celok Lek 2013;141(3-4): 163-8. DOI: $10.2298 / \mathrm{sarh} 1304163 \mathrm{n}$

12. Bansal N, Gupta ND, Bey A, Sharma VK, Gupta $\mathrm{N}$, Trivedi $\mathrm{H}$. Impact of nonsurgical periodontal therapy on total antioxidant capacity in chronic periodontitis patients. J Indian Soc Periodontol 2017;21(4):291-5. DOI: 10.4103/ jisp.jisp_281_15

13. Pendyala G, Thomas B, Joshi SR. Evaluation of total antioxidant capacity of saliva in type 2 diabetic patients with and without periodontal disease: A case-control study. N Am J Med Sci 2013;5(1):51-7. DOI: 10.4103/19472714.106208

14. Chandra RV, Srinivas G, Reddy AA, Reddy BH, Reddy C, Nagarajan S, et al. Locally delivered antioxidant gel as an adjunct to nonsurgical therapy improves measures of oxidative stress and periodontal disease. J Periodontal Implant Sci 2013;43(3):121-9. DOI: 10.5051/ jpis. 2013.43.3.121

15. Rattanasuwan K, Rassameemasmaung $\mathrm{S}$, Sangalungkarn V, Komoltri C. Clinical effect of locally delivered gel containing green tea extract as an adjunct to non-surgical periodontal treatment. Odontology 2016;104(1):89-97. DOI: $10.1007 / \mathrm{s} 10266-014-0190-1$

16. Deshpande N, Deshpande A, Mafoud S. Evaluation of intake of green tea on gingival and periodontal status: An experimental study. J Interdisciplin Dent 2012; 2(2):108-12. DOI: 10.4103/2229-5194.100603

17. Varghese JM, Bhat V, Bhat GS, Rao N. 
Evaluation of Glutathione-S-transferase and ceruloplasmin levels in gingival crevicular fluid and gingival tissue as diagnostic markers for chronic periodontitis. Adv Biosci Biotechnol 2012;3:437-41. DOI: 10.4236/ abb.2012.324061

18. Hrishi TS, Kundapur PP, Naha A, Thomas BS, Kamath S, Bhat GS. Effect of adjunctive use of green tea dentifrice in periodontitis patients - A randomized controlled pilot study. Int J Dent Hyg 2016;14(3):178-83. DOI: 10.1111/ idh. 12131

19. Al-Shawi NN, Kahtan AHM. Possible antiinflammatory effect of aqueous green tea extract against an acute inflammation induced by egg white in rats. Iraq J Pharm Sci 2009; 18(2).73-9.

20. Dahiya P, Kamal R, Gupta R, Bhardwaj R, Chaudhary K, Kaur $S$. Reactive oxygen species in periodontitis. J Indian Soc Periodontol 2013;17(4):411-6. DOI: $10.4103 / 0972-$ 124X.118306

21. Manjunath RGS. Role of antioxidants as an adjunct in periodontal therapy. J Acad Adv Dent Res 2011;2(2):9-16.

22. Chava VK, Vedula BD. Thermo-reversible green tea catechin gel for local application in chronic periodontitis: A 4-week clinical trial. J Periodontol 2013;84(9):1290-6. DOI: 10.1902/ jop. 2012.120425

23. Venkateswara B, Sirisha K, Chava VK. Green tea extract for periodontal health. J Indian Soc Periodontol 2011;15:18-22.

24. Sharma S, Bhuyan L, Ramachandra $S$, Sharma S, Dash KC, Dhull KS. Effects of green tea on periodontal health: A prospective clinical study. J Int Oral Health 2017;9:39-44. DOI: 10.10.4103/jioh.jioh $37 \quad 17$

25. Kudva P, Tabasum ST, Shekhawat NK. Effect of green tea catechin, a local drug delivery system as an adjunct to scaling and root planing in chronic periodontitis patients: A clinicomicrobiological study. J Indian Soc Periodontol 2011;15(1):39-45. DOI: 10.4103/0972-124X.82269

26. Nugala B, Namasi A, Emmadi P, Krishna PM. Role green tea as an antioxidant in periodontal disease: The Asian paradox. J Ind Soc Periodont 2012;16(3):313-6. DOI: 10.10.4103/0972-124X.100902

27. Wati SM, Istiati I, Soesilawati P. Characterization of lactoferrin in gingival crevicular fluid of chronic periodontitis patient. Dent J Maj Ked Gi 2014;47(3):141-5. DOI: 10.20473/j.djmkg.v47. i3.p141-145

28. Gupta G. Gingival crevicular fluid as a periodontal diagnostic indicator- I: Host derived enzymes and tissue breakdown products. J Med Life 2012; 5(4):390-7.

29. Chapple ILC, Brock G, Eftimiadi C, Matthews JB, Glutathione in Gingival Crevicular Fluid and its Relation to Local Antioxidant Capacity in Periodontal health and Disease. J Clin Pathol: Mol Pathol 2002;55:367-73.

30. Forouzanfan A, Arab HR, Shafaee H, Mokhtari MR, Golestani S. The effect of green tea mouthwash (Camellia sinensis) on wound healing following periodontal crown lengthening surgery; a double blind randomized controlled trial. Open J Stomatology 2012;2:369-72. 